\title{
PENERAPAN METODE PEMBELAJARAN PEER TEACHING UNTUK MENINGKATKAN HASIL BELAJAR MATA KULIAH KALKULUS
}

\author{
Ayi Ahmad Maulana Yusup ${ }^{1}$, Ani Interdiana Candra Sari ${ }^{2(*)}$ \\ Universitas Indraprasta PGRI, Jakarta ${ }^{12}$ \\ tetracosmic@yahoo.com ${ }^{1}$, incasani26@gmail.com ${ }^{2}$
}

Received: 25 Desember 2019

Revised: 15 Februari 2020

Abstract

Accepted: 15 Maret 2020

Penelitian ini berjudul Penerapan Metode Pembelajaran Peer Teaching untuk Menaikkan nilai Mata Kuliah Kalkulus. Tujuan dari penelitian ini adalah: untuk mengetahui penerapan metode pembelajaran peer teaching dalam upaya meningkatkan hasil belajar Kalkulus Mahasiswa Program Studi Teknik industri Universitas Indraprasta PGRI. Metode yang akan digunakan adalah dengan eksperimen. Peneliti akan menggunakan dua kelas sebanyak 73 mahasiswa, kelas F sebagai kelas kontrol dengan metode ceramah dan kelas $\mathrm{G}$ sebagai kelas eksperimen melalui model pembelajaran tutor sebaya, dari kedua metode yang digunakan peneliti akan melihat dan membandingkan hasil belajar mahasiswa/i. Berdasarkan penelitian dan perhitungan SPSS diperoleh hasil penelitian sebagai berikut: (1) kedua data normal dan homogen, (2) terdapat perbedaan dalam penerapan model pembelajaran peer teaching dengan metode ceramah yang disampaikan kepada mahasiswa/i. Hasil belajar mahasiswa/i yang menggunakan metode peer teaching lebih tinggi secara signifikan dari pada mahasiswa/i yang menggunakan metode ceramah pada pembelajaran kalkulus.

Keywords: Metode Peer Teaching, Metode Ceramah, Hasil Belajar Kalkulus

(*) Corresponding Author: $\quad$ Ani Interdiana Candra Sari, incasani26@gmail.com, 081282417766

How to Cite: Yusup, A. A. M. \& Sari, A. I. C. (2020). Penerapan Metode Pembelajaran Peer Teaching Untuk Meningkatkan Hasil Belajar Mata Kuliah Kalkulus. Research and Development Journal of Education, 6(2), 01-12.

\section{INTRODUCTION}

Undang-Undang Dasar 1945 menegaskan bahwa setiap warga negara Indonesia berhak mendapatkan pendidikan. Mencapai gelar akademik yang tinggi merupakan bagian penting untuk dapat memajukan bangsa, maka perlu mendapatkan perhatian yang baik. Undang-Undang No. 20 Tahun 2003 tentang Sisdiknas merupakan salah satu upaya pembaharuan dalam penyelenggaraan pendidikan, sehingga dapat meningkatkan mutu pendidikan. Undang-undang diatas mengatakan pembelajaran adalah usaha sadar dan terprogram demi menciptakan lingkungan yang kondusif dan proses pembelajaran demi terwujudnya potensi peserta didik agar memiliki kemampuan dalam ranah kognitif, afektif, dan psikomotorik.

Undang-Undang Dasar 1945 menegaskan bahwa setiap warga negara Indonesia berhak mendapatkan pendidikan. Mencapai gelar akademik yang tinggi merupakan bagian penting untuk dapat memajukan bangsa, maka perlu mendapatkan perhatian yang baik. Undang-Undang No. 20 Tahun 2003 tentang Sisdiknas merupakan salah satu upaya pembaharuan dalam penyelenggaraan pendidikan, sehingga dapat meningkatkan mutu pendidikan. Undang-undang diatas mengatakan pembelajaran adalah usaha sadar dan terprogram demi menciptakan lingkungan yang kondusif dan proses pembelajaran demi 
terwujudnya potensi peserta didik agar memiliki kemampuan dalam ranah kognitif, afektif, dan psikomotorik.

Airasian (2010) menyebutkan bahwa pembelajaran menekankan pada model untuk membuat peserta didik menyadari dan bertanggung jawab atas pengetahuan dan pemikiran mereka sendiri. Keberadaan dosen menggambarkan sistem yang berarti di dalam proses pendidikan, sehingga dosen memiliki peran dan tanggung jawab yang besar dalam dunia pendidikan. Hal tersebut, mengisyaratkan bahwa setiap dosen wajib mempunyai kemampuan akademik dan pemahaman sebagai agen pembelajaran.

Proses pembelajaran diperguruan tinggi harus dilakukan semenyanangkan mungkin, agar peserta didik tidak merasa bosan dalam pembelajaran. Dengan demikian akan menciptakan kreativitas dalam segala bidang dengan tetap mengindahkan potensi peserta didik. Seperti yang diungkapkan Hayati (2017) mengkategorikan hasil belajar dalam tiga ranah atau kawasan yaitu (1) ranah kognitif (cognitive domain), (2) ranah afektif (affective domain), dan (3) ranah psikomotorik (motor skill domain). Proses pembelajaran pada saat ini kebanyakan yang diukur adalah kemampuan aspek kognitif semata, sedangkan dari aspek afektifnya hanya sedikit diberikan pada saat proses pembelajaran. Padahal aspek afektif juga penting untuk pembentukan karakter mahasiswa sehubungan dengan kurikulum pendidikan tinggi yang diterapkan pada proses pembelajaran perguruan tinggi. Temuan yang menunjukkan bahwa aspek afektif mahasiswa yang masih rendah pada saat proses pembelajaran terlihat dari hal-hal yang dilakukan mahasiswa sebagai berikut:

1. Sikap penerimaan, pada sikap penerimaan mahasiswa kurang tertarik mendengar penjelasan dari dosen terkait dengan materi perkuliahan.

2. Sikap partisipasi, pada sikap partisipasi mahasiswa masih kurang baik, hal ini terlihat pada saat dosen usai menyampaikan materi perkuliahan, mahasiswa tidak memberikan respon terhadap penjelasan bahan ajar yang telah dipaparkan dosen dari segi menjawab dan memberikan pertanyaan kedosen.

3. Penentuan sikap, penentuan sikap mahasiswa terhadap rangsangan yang datang masih rendah. Hal ini ditunjukkan dengan kurangnya rasa peduli dan tanggung jawab mahasiswa dalam menyelesaikan soal latihan yang disampaikan oleh dosen.

4. Sikap organisasi, sikap organisasi yang dimiliki mahasiswa masih rendah. Hal ini ditunjukkan dengan masih banyaknya mahasiswa yang tidak dapat membentuk dirinya agar siap mengikuti perkuliahan, mahasiswa menunggu arahan dari dosen dalam memulai perkuliahan.

5. Sikap pembentukan pola hidup, sikap pembentukan pola hidup mahasiswa juga belum menunjukkan hal yang positif. Hal ini ditunjukkan dengan minimnya pembendaharaan pengetahuan mahasiswa terhadap materi pembelajaran karena mahasiswa tidak mempunyai catatan ataupun buku pegangan, bahkan mahasiswa kurang berminat mengunjungi perpustakaan. (Hayati, 2017)

Selain itu, mahasiswa yang belajar mata kuliah kalkulus pada perguruan tinggi sebagian besar berasal dari multi disiplin ilmu pada tingkat Sekolah Menengah Atas, ditambah lagi sebagian besar dosen hanya memanfaatkan model pembelajaran konvensional dan minim memanfaatkan keberagaman model pembelajaran. Berdasarkan observasi awal didapatkan fakta bahwa rata-rata dari mereka saat sekolah sangat menghindari atau tidak menyukai mata pelajaran matematika atau menghitung, dengan alasan sulit, membosankan, banyak rumus yang harus dihafal, monoton, ilmu pasti, dan lain-lain. Keadaan tersebut akan berdampak pada mata pelajaran kalkulus. Menurut Sodikin dalam (Noersasongko, 2009) pembelajaran yang dilakukan dengan metode non kooperatif atau ceramah hanya menekankan pada teacher centered dan tidak sesuai dengan kebutuhan peserta didik dan perkembangan ipteks. Hal ini juga senada disampaikan oleh Philip R. Wallace dalam (Noersasongko, 2009) bahwa suatu 
pembelajaran metode ceramah atau tradisional lebih menekankan pada keaktifan pendidik dan mengabaikan kemampuan peserta didik, sehingga kemampuan kognitiflah yang menjadi dasar keberhasilan pembelajaran. Padahal keberhasilan siswa tidak hanya bergantung dari satu hal saja melainkan banyak faktor yang mempengaruhinya, seperti kecerdasan, lingkungan, kemauan, dan pembimbing.

Oleh sebab itu, dosen harus mempunyai kreativitas tinggi dalam memilih model pembelajaran yang menarik minat mahasiswa. Keberhasilan dalam mencapai hasil belajar yang maksimal melalui sistem pendidikan akan bergantung pada kreatifitas pendidik dalam menyampaikan materi. Sebagai pendidik harus menguasai berbagai metode mengajar yang banyak tidak hanya ceramah. Dibutuhkan kecerdasan bagi pendidik untuk dapat menyesuaikan metode yang pas agar mudah menyampaikan materi yang akan diajarkan.

Djamarah (2008) metode pembelajaran adalah "suatu metode yang dimanfaatkan untuk mempermudah mencapai tujuan'. Metode sangat diperlukan pendidik agar penyampaian materi mudah diterima untuk hasil yang maksimal setelah berakhirnya proses mengajar. Salah satu metode yang bisa dimanfaatkan dalam mengajar adalah Peer Teaching merupakan cara belajar yang melibatkan mahasiswa secara aktif. Satu mahasiswa akan mengajari teman-temanya yang belum mengerti dengan materinya. Setelah pendidik memberikan ceramah, dosen membagi mahasiswa dalam kelompok yang terdiri dari 4-6 mahasiswa dengan tingkat kecerdasan yang berbeda-beda (Dianawati, 2015). Dengan metode pembelajaran Peer Teaching pembelajaran harus didominasi oleh mahasiswa/i, sehingga tercipta mahasiswa/i yang mampu berinteraksi dengan mahasiswa/i yang lain dan saling menghargai. Metode belajar tutor sebaya adalah model pembelajaran yang dapat memberikan bantuan dan arahan bagi teman sebaya dalam menciptakan pembelajaran yang kondusif. Hamalik, 2009 (dalam Hayati, 2017). Tutor sebaya (Peer Teaching) yaitu peserta didik yang ditunjuk oleh pendidik yang memiliki kecerdasan diatas rata-rata yang bertugas dalam membantu teman sebaya untuk meraih hasil belajar yang maksimal. (Arikunto, 2008).

Menurut Purwanto (2016) hasil belajar ialah perubahan perilaku seseorang akibat belajar. Menurut Suprijono (2015) luaran dalam mencari ilmu yaitu tindakan, aturan, pemahaman, kemampuan, penghargaan serta keterampilan. Menurut Sudjana (2014) produk menuntut ilmu adalah kompetensi yang dikuasai peserta didik selama mengikuti proses pembelajaran. Menurut pemikiran Gagne dalam Suprijono (2015) hasil belajar berupa (1) laporan komunikasi lisan adalah kecakapan berbahasa secara verbal dan tulis. Tanggapan terhadap rangsangan sesuai karakteristik dengan respon istimewa. Kemampuan itu tak membutuhkan trik atribut maupun penerapan aturan, (2) kecerdasan adalah kecakapakan dalam menginterprestasikan teori dan simbol. Kecerdasan meliputi kecakapan mengkelompokkan, kecakapan logis-paduan data-teori serta menyebarluaskan dasar-dasar pengetahuan. Kecerdasan adalah kecakapan dalam tindakan pengetahuan yang memiliki ciri keterampilan khas, (3) ranah pengetahuan adalah kemampuan dalam mendistribusikan serta mengantarkan ketindakan pengetahuan individual. Kemampuan kecerdasan terdiri dari pemahaman teori serta aturan menyelesaikan masalah, (4) keterampilan motoric adalah kecakapan dalam menjalankan kegiatan yang berkaitan dengan olah fisik dan bagiannya, (5) afektif yaitu keterampilan merespon keadaan sesuai dengan pengamatan yang dilihat atau dikerjakan. Afektif merupakan kemampuan untuk menciptakan dan mewujudkan aturan-aturan. Afektif adalah kecakapan mewujudkan aturan-aturan sebagai pedoman dalam bertindak.

Menururt Bloom dalam Suprijono (2015), hasil belajar terdiri dari 3 aspek, yaitu: kecakapan pengetahuan, sikap, dan psikomotorik, (1) domain pengetahuan meliputi knowledge (pengetahuan, ingatan), comprehension (pengertian, menjabarkan, merangkum, ilustrasi), Aplikasi (melaksanakan), Analisis (memaparkan dan membentuk 
jejaring), Sintesis (mengoordinasikan, menyusun, membuat jaringan), serta Evaluasi (menilai), (2) domain afektif (sikap) meliputi receiving (mengakui), responding (tanggapan), valuing (harga), organization (organisasi), characterization (karakteristik), (3) ranah keterampilan terdiri dari inisial, pra rutin, dan rutunitas/rountinized. Psikomotor meliputi kecakapan mencipta, proses, jasmani, interaksi, mengelolah serta intelektual. Sedangkan Lindgren menyatakan bahwa luaran dari nilai belajar adalah (1) kecakapan, (2) informasi, (3) pengertian, (4) dan sikap. Menurut Kingsley dalam Sudjana (2014:22) luaran nilai pembelajaran terdiri dari (1) kecakapan serta penguasaan, (2) pengetahuan dan pengertian, (3) sikap dan cita-cita. Berdasarkan beberapa pendapat para pakar dapat ditarik kesimpulan bahwa luaran nilai pembelajaran merupakan proses perubahan dari segi pengetahuan, sikap, dan keterampilan peserta didik secara nyata setelah dilakukan proses pembelajaran.

Menurut Sudjana (2004) nilai yang diperoleh peserta didik ditentukan oleh dua aspek utama, yaitu faktor internal dan eksternal. Faktor internal adalah faktor yang berasal dari diri peserta didik yaitu meliputi (1) keterampilan diri peserta didik (2) motivasi belajar, (3) minat dan perhatian, (4) sikap dan kebiasaan belajar, (5) ketekunan, sosial ekonomi, (6) aspek jasmani dan rohani. Hasil belajar pada dasarnya dinilai dari dua jenis penilaian, yaitu peneliaian berbentuk tes dan non tes.

Menurut Hamdayana (2016) metode pembelajaran ialah cara yang digunakan pendidik dalam memaparkan pelajaran kepada peserta didik. Menurut Siregar \& Nara (2014) metode pembelajaran dapat didefinisikan sebagai cara yang digunakan guru, sehingga dalam menjalankan fungsinya, metode merupakan alat yang digunakan dalam menggapai sasaran belajar.Berdasarkan pengertian dari para ahli dapat ditarik kesimpulan bahwa model belajar adalah strategi yang digunakan oleh pendidik dalam menyampaikan pembelajaran guna menggapai sasaran belajar.

Metode ceramah, Metode ini boleh dikatakan sebagai metode konvensional, karena sudah digunakan sejak dulu. Metode ceramah digunakan untuk menjalin hubungan secara verbal antara pendidik dan peserta didik dalam pembelajaran. Metode ceramah ialah cara penyajian pelajaran yang dilakukan guru dengan penjelasan lisan yang hanya melibatkan komunikasi satu arah. (Djamarah dan Zain, 2013)

Metode pembelajaran peer teaching menurut Depdiknas dalam Majid (2013) merupakan aktifitas pembelajaran yang dilakukan seorang siswa kepada siswa lainnya dan salah satu siswa itu lebih memahami materi pembelajaran. Menurut Makarao (2009) Tutor Sebaya adalah metode pelatihan yang memfasilitasi peserta untuk mengajarkan suatu pengetahuan atau keterampilan tertentu kepada sesama peserta lainnya. Menurut Djamarah dan Zain (2013) terkadang peserta didik lebih mengerti apa yang disampaikan teman sebayanya ketimbang penjelasan dari pendidik untuk melaksanakan program perbaikan. Berdasarkan beberapa pengertian Tutor Sebaya yang telah diuraikan dapat ditarik kesimpulan bahwa model belajar peer teaching ialah kegiatan bimbingan pembelajaran oleh teman sebaya yang lebih memahami materi pelajaran kepada mahasiswa/i yang belum terlalu paham terhadap materi yang diberikan dosen.

Menurut Sudjana (2005), menjelaskan keunggulan metode Tutor Sebaya adalah sebagai berikut: (1) Siswa/i belajar dengan kondusif karena mereka berpartisipasi dalam menciptakan lingkungan belajar yang sesuai, (2) siswa/i mempunyai antusias yang tinggi dalam proses pembelajaran, (3) menciptakan lingkungan yang kondusif dalam proses pembelajaran sehingga tercipta tanya jawab yang sehat dalam pembelajaran, (4) menghasilkan kemampuan dalam ranah kognitif, afektif, dan psikomotorik bagi mahasiswa/i.

Menurut Djamarah dan Zain (2013) selain mempunyai beberapa manfaat, model belajar peer teaching juga mempunyai kekurangan. Kekurangan metode Tutor Sebaya ialah (1) siswa yang dibantu sering belajar kurang serius dan saling mengandalkan, 
karena berhadapan dengan kawannya, sehingga hasilnya kurang memuaskan, (2) diantara mereka ada yang sungkan untuk bertanya, khawatir ketidakbisaannya menjadi rahasia umum bagi kawannya, (3) tidak semua kelas dapat diterapkan metode pembelajaran tutor sebaya, hal ini disebabkan adanya perbedaan kecerdasan, kemampuan menyampaikan, jenis kelamin antara tutor dengan peserta didik yang menjadi bimbingannya. (4) dalam menerapkan metode tutor sebaaya pendidik sulit untuk menentukan tutor yang tepat dalam kelompok yang dibimbing, (5) tidak semua tutor yang dipilih dapat menyampaikan ulang kepada teman yang menjadi bimbingannya. Kelemahan model belajar teman sejawat menurut Sudjana (2005) ialah sebagai berikut: (1) menghabiskan waktu yang relatif lama, (2) kegiatan serta pembicaraan dalam proses belajar akan dikuasai oleh siswa yang pandai bicara, (3) dan pembelajaran dapat menyimpang dari arah pembelajaran. (4) terjadi saling mengandalkan teman dalam kelompok yang sama.

Menurut Schunk (2012) tahapan pembelajaran dengan tutor sebaya pada umumnya mengikuti pola sebagai berikut: (1) Guru menyusun kelompok belajar. Setiap kelompok beranggotakan 3 atau 5 peserta didik yang mempunyai variasi dalam hal kecakapan. Pendidik akan mengkelompokan peserta didik yang mempunyai kecakapan yang tinggi sebagai kelompok tutor. Banyaknya tutor sebanding dengan kelompok yang dibuat. (2) pendidik mengajari tutor berkaitan dengan bahan ajar yang akan disampaikan keteman-teman bimbingannya, memaparkan tugas yang harus diselesaikan dan tahapan penilaian. (3) pendidik secara ringkas memaparkan bahan ajar kepada siswa dan membuka sesi brainstorming sekitar 5 - 10 menit. (4) Guru memberikan latihan soal yang wajib diselesaikan dan tata cara melakukan evaluasi. (5) Tutor sebaya menolong rekannya untuk menyelesaikan soal latihan serta memaparkan penjelasan bahan ajar yang tidak dimengerti rekannya dalam kelompok (6) pendidik memonitoring proses pembelajaran serta mengevaluasi kemampuan masing-masing tutor dan peserta didik lainnya. (7) Guru, tutor, serta siswa membagikan penilaian pembelajaran untuk menentukan langkah selanjutnya.

Langkah-langkah kegiatan pembelajaran menggunakan model belajar peer teaching menurut Mulyatiningsih (2011) adalah sebagai berikut: (1) pendidik menentukan tim, tiap tim berjumlah 3 sampai 4 peserta didik yang mempunyai keanekaragaman dalam hal kecakapan. Tiap tim akan ditunjuk sebagai tutor teman sebaya yang mempunyai kecerdasan dalam hal akademik. (2) Guru menjelaskan tentang prosedur pengerjaan soal latihan dengan model belajar Tutor Sebaya, pertanggung jawaban tim, evaluasi pembelajaran dengan peer assessment dan self aseessment. (3) pendidik memaparkan bahan ajar serta membuka kesempatan diskusi untuk seluruh siswa berkaitan dengan bahan ajar yang tidak dimengerti. (4) Guru memberi tugas kelompok, bagi siswa yang belum bisa menyelesaikan soal latihan bisa menayakan kepada tutor dalam tim. (5) pendidik memonitoring proses pembelajaran serta mengevaluasi kemampuan masingmasing tutor dan peserta didik lainnya. (6) pendidik, pembimbing, serta siswa mengevaluasi pembelajaran guna menentukan langkah selanjutnya.

Berdasarkan teori langkah-langkah pembelajaran peer teaching para pakar yang telah diuraikan di atas, langkah-langkah pembelajaran dengan model belajar peer teaching dalam riset, sebagai berikut:

1. Dosen menyusun kelompok belajar. Setiap kelompok beranggotakan 5 orang yang memiliki kompetensi beragam. Dosen mengelompokkan mahasiswa/i yang mempunyai kecakapan yang lebih baik daripada temannya untuk dijadikan tutor dalam kelompok. Banyaknya tutor sebanding dengan banyaknya kelompok yang dibuat.

2. Dosen menjelaskan wewenang, tanggung jawab tutor, tugas dan penilaian yang akan dilaksanakan dan mendidik tutor mengenai bahan ajar yanag akan disampaikan dikelas satu minggu sebelum pembelajaran dimulai. 
3. Dosen memaparkan bahan ajar dengan ringkas kepada seluruh mahasiswa serta membuka peluang untuk bertanya.

4. Dosen memberi tugas, dengan catatan mahasiswa yang mengalami kesukaran menyelesaikan soal latihan bisa menanyakan kepada tutor dan memberikan penjelasan bahan ajar yang tidak dimengerti oleh rekannya dalam kelompok.

5. Dosen memonitoring proses pembelajaran serta mengevaluasi kemampuan masingmasing tutor dan mahasiswa/i lainnya.

6. Dosen, tutor, dan mahasiswa menilai pembelajaran guna menentukan langkah pembelajaran selanjutnya.

Dosen saat proses belajar dengan model Tutor Sebaya ini berperan sebagai fasilitator yang mengawasi kelancaran pelaksanaan pembelajaran dengan memberikan pengarahan dan bantuan jika mahasiswa mengalami kesulitan dalam belajar dan membimbing secara terbatas, artinya dosen hanya melakukan intervensi ketika benarbenar diperlukan oleh mahasiswa.

\section{METHODS}

Riset dalam penelitian ini menggunakan teknik eksperimen semu (quasi experiment), karena dalam penelitian ini peneliti tidak mengontrol semua variabel yang relevan. Penelitian eksperimen mengambil dua kelompok, yaitu kelompok kontrol serta kelompok eksperimen yang memiliki kemampuan setara dengan menerapkan model pembelajaran yang berbeda. Kelompok eksperimen diberi perlakuan metode Peer Teaching (Pembelajaran Tutor Sebaya), sedangkan kelompok kontrol diberi pembelajaran konvensional. Rancangan penelitian ini adalah Posttes-Only Control Design yang berbentuk quasi eksperimen (Sugiyono, 2009) adalah sebagai berikut:

Tabel 1.

Posttest-Only Control Group Design

\begin{tabular}{lll}
\hline Kelompok & Perlakuan & Posttest \\
\hline Eksperimen & $\mathrm{X}$ & $\mathrm{O}$ \\
Kontrol & - & $\mathrm{O}$ \\
\hline Sumber : Peneliti &
\end{tabular}

Populasi dalam penelitian ini adalah seluruh Mahasiswa/i Program Studi Teknik Industri semester 1 kelas Reguler yang berjumlah 358 mahasiswa/i dari 9 kelas. Sampel penelitian ini sebanyak 73 mahasiswa/i yang ditentukan dengan menggunakan teknik purposive sampling. Sampel yang diperoleh dari populasi di mana kelas eksperimen menggunkan metode Peer Teaching (Pembelajaran Sesama Teman) dan kelas kontrol menggunakan model pembelajaran konvensional.

Berikut ini adalah ringkasan hasil ujicoba instrument penelitian:

Tabel 2.

Ringkasan Hasil Uji Coba Instrumen

\begin{tabular}{ccccc}
\hline No & Korelasi & Tingkat Kesukaran & Daya Pembeda & Reliabel \\
\hline 1 & valid & Sedang & Revisi & \\
2 & valid & Sedang & Revisi & \\
3 & valid & Sedang & Terima & 0,864 \\
4 & valid & Mudah & Revisi & \\
5 & valid & Sedang & Terima & \\
\hline \multicolumn{5}{l}{ Sumber : Peneliti }
\end{tabular}




\section{RESULTS \& DISCUSSION}

Berikut ini adalah data hasil perhitungan rata-rata skor Peran Kepala Sekolah dalam Meningkatkan Profesionalisme Guru di SMP Muhammadiyah 36 Jakarta Selatan.

\section{Tabel 1.}

Rata-Rata Hitung Skor Peran Kepala Sekolah Dalam Meningkatkan Profesionalisme Guru

\begin{tabular}{ccccccc}
\hline Variabel & \multicolumn{2}{c}{ Peran Kepala Sekolah dalam Meningkatkan Profesionalisme Guru } \\
\hline Dimensi & Leadership & Supervisor & Motivator & Inovator & Manajer & Educator \\
Jumlah Soal & 6 & 6 & 4 & 3 & 6 & 5 \\
Skor & 295 & 270 & 182 & 138 & 280 & 254 \\
Rata-rata & 49,17 & 45 & 45,5 & 46 & 46,67 & 50,8 \\
\hline
\end{tabular}

Sumber: Diolah Peneliti, 2019

Berdasarkan data diatas, kemudian dilakukan perhitungan sebagai berikut :

$$
\frac{49,17+45+45,5+46+46,67+50,8}{6}=47,19
$$

Kemudian nilai tersebut di interpretasikan ke dalam tabel berikut ini :

Tabel 2.

Tabulasi Skor

\begin{tabular}{ccc}
\hline No & Nilai Skor & Kategori \\
\hline 1 & $95-120$ & Sangat Baik \\
2 & $70-94$ & Baik \\
3 & $45-69$ & Cukup Baik \\
4 & $20-44$ & Kurang Baik \\
\hline
\end{tabular}

\section{Discussion}

Tabel 3.

Pengujian Normalitas

\begin{tabular}{lcccccc}
\hline & \multicolumn{3}{c}{ Kolmogorov-Smirnov } & \multicolumn{3}{c}{ Shapiro-Wilk } \\
& Statistic & Df & Sig. & Statistic & Df & Sig. \\
\hline X1_Kelas_Eksperimen & 0,108 & 35 & $0,200^{*}$ & 0,943 & 35 & 0,067 \\
X2_Kelas_Kontrol & 0,116 & 35 & $0,200^{*}$ & 0,980 & 35 & 0,751 \\
\hline
\end{tabular}

Sumber: Diolah Peneliti, 2019

Tabel 4.

Pengujian Homogenitas

\begin{tabular}{cccc}
\hline Levene Statistic & df1 & df2 & Sig. \\
\hline 3,271 & 1 & 71 & 0,075 \\
\hline \multicolumn{4}{l}{ Sumber: Diolah Peneliti, 2019}
\end{tabular}

Tabel 5.

Ringkasan Hasil Penelitian

\begin{tabular}{lcc}
\hline & Sig (2-tailed) & t hitung \\
\hline Hasil Belajar Kalkulus & 0,046 & 2,034 \\
\hline Sumber: Diolah Peneliti, 2019 &
\end{tabular}


Berdasarkan tabel 3 pengujian dilakukan dengan menggunakan uji Kolmogorrov smirnov dengan keterangan adalah sama dengan uji liliefors. Didapat untuk variabel hasil belajar kelompok eksperimen dan kelas kontrol $(0,200>0,05)$, karena tingkat signifikansi atau nilai probabilitas di atas 0,05 maka dikatakan distribusi kedua sampel adalah normal.

Berdasarkan tabel 4 pengujian dilakukan dengan menggunakan uji Fisher. Didapat untuk variabel hasil belajar kalkulus baik kelas eksperimen dan kontrol $(0,075$ > 0,05), karena tingkat signifikansi atau nilai probabilitas di atas 0,05 maka dikatakan distribusi kedua sampel adalah homogen.

Berdasarkan tabel 5 diketahui nilai sig $0,046<0,05$ atau $t$ hitung $(2,034)>t$ tabel $(1,9963)$. Oleh karena itu, bisa disimpulkan bahwa hasil belajar kalkulus mahasiswa/i yang menggunakan metode peer teaching lebih tinggi daripada hasil belajar kalkulus mahasiswa/i yang menggunakan metode konvensional ataupun dapat dikatakan bahwa penerapan metode peer teaching berhasil menaikkan nilai belajar kalkulus mahasiswa/i. Hal ini disebabkan karena metode peer teaching dapat membantu mahasiswa/i yang kurang aktif menjadi lebih aktif dalam proses pembelajaran sehingga dapat membantu mahasiswa/i tersebut dalam memahami pelajaran yang berdampak pada meningkatkan prestasi belajar. Salah satu indikator seseorang sudah cukup menguasai suatu materi adalah ketika seseorang tersebut mampu menerangkan atau mengajarkannya pada orang lain.

Berdasarkan temuan pada penelitian yang telah dilakukan proses pembelajaran menggunakan metode klasikal dalam hal ini metode ceramah, sebagian mahasiswa/i kurang aktif dalam proses pembelajaran yang berdampak pada mahasiswa/i cepat bosan dan tidak bersemangat dalam mengikuti proses pembelajaran. Metode pembelajaran ceramah dapat dikatakan adalah metode satu arah yang berpusat pada dosen, sehingga metode ini menjadikan dosen lebih aktif dalam proses pembelajaran. Jika dosen melemparkan pertanyaan ada yang bertanya atau belum paham mereka diam. Untuk membuktikan mereka paham atau tidak diberikan latihan, nah terbukti dari hasil latihan mereka masih mendapat nilai dibawah 50 .

Sedangkan kelas yang menggunakan metode peer teaching mahasiswa/i lebih aktif dalam mengerjakan latihan yang diberikan, jika mereka tidak paham langsung bertanya dengan ketua tim, semangat jika ditunjuk untuk mengerjakan dipapan tulis, catatan rapih dan lengkap, banyak pertanyaan yang diajukan ke ketua tim, aktifitas banyak didalam kelas terbukti tidak ada yang mondar-mandir keluar kelas. Sehingga memotivasi mereka untuk meningkatkan hasil belajar, ini terlihat dari nilai latihan diatas 70, meskipun masih ada beberapa mahasiswa/i yang mendapat nilai 50 .

Hasil analisis menunjukkan bahwa hasil belajar kalkulus mahasiswa/i yang menggunakan metode peer teaching lebih tinggi daripada hasil belajar kalkulus mahasiswa/i yang menggunakan metode konvensional atau dapat dikatakan penerapan metode peer teaching dapat meningkatkan hasil belajar kalkulus mahasiswa/i.

Hasil penelitian ini didukung oleh riset yang dibuat Hayati (2017), yang menyatakan bahwa ranah sikap saat diterapkan metode belajar tutor sebaya lebih baik secara siginifikan dengan mahasiswa yang pembelajarannya diterapkan model pembelajaran konvensional.

Selanjutnya, penelitian lain yang mendukung hasil penelitian ini dilakukan oleh Nuki Hastuti (2018), yang menyatakan bahwa penerapan metode pembelajaran Tutor Sebaya pada mata pelajaran Desain Grafis dapat meningkatkan keaktifan dan hasil belajar siswa kelas X Multimedia 1. Rata-rata persentase keaktifan belajar siswa pada siklus I sebesar $49.3 \%$ mengalami peningkatan pada siklus II menjadi $62.75 \%$. Peningkatan keaktifan belajar siswa terdapat pada indikator memperhatikan penjelasan materi dari guru, memperhatikan penjelasan materi dari tutor sebaya, mendengarkan penjelasan materi dari guru, mendengarkan penjelasan materi dari tutor sebaya, mengajukan 
pertanyaan kepada teman, dapat mengemukakan pendapat ketika diskusi, dan membuat catatan materi sudah sebagian besar siswa telah berperan serta dalam pembelajaran. Keaktifan belajar siswa harus dinaikkan kembali diindikator berani menjawab pertanyaan dari guru, berani menjawab pertanyaan dari teman, dan menuliskan pertanyaan pada lembar pertanyaan, karena persentase yang diperoleh hanya sedikit dan belum mencapai $50 \%$ meskipun sudah memenuhi target yang ditentukan. Hasil belajar siswa mengalami peningkatan yang dibuktikan dengan naiknya persentasi ketuntasan nilai pembelajaran peserta didik pada setiap siklus. Persentase ketuntasan hasil belajar kognitif siswa pada pra siklus sebesar $51.61 \%$, kemudian mengalami peningkatan pada siklus I menjadi 61.3\% dan menjadi $77.4 \%$ pada siklus II. Persentase ketuntasan hasil belajar psikomotorik siswa pada pra siklus sebesar $64.51 \%$, kemudian mengalami peningkatan pada siklus I menjadi $77.4 \%$ dan menjadi $87 \%$ pada siklus II.

Hal ini sejalan dengan hasil penelitian yang dikemukan oleh Dhini Kurnia (2014) bahwa penerapan metode pembelajaran kooperatif dapat meningkatkan kemampuan dan pemahaman mengenai pemrograman web yang pada akhirnya dapat meningkatkan nilai akademik mahasiswa. Mahasiswa dapat bertukar pikiran kepada kelompok dan dosen, sehingga mahasiswa menjadi kreatif.

Sejalan dengan hasil penelitian Nugria Bunga (2016) dapat disimpulkan bahwa penerapan model belajar diskusi dapat meningkatkan minat belajar mahasiswa Universitas Negeri Makassar dalam katogori cukup tinggi. Minat belajar diukur melalui indikator perhatian, perasaan, dan motif.

Sejalan dengan Ratna Dewi (2018) Hasil penelitian menunjukkan bahwa: (1) Ada delapan model pembelajaran yang diterapkan oleh guru, dan yang representatif adalah model pembelajaran kooperatif (model 2) dibandingkan dengan model pendekatan CTL (model 6) serta model lainnya. Model belajar yang didapat peserta didik dalam pembelajaran yaitu model belajar matematika realistik (model 7) yang akan dibandingkan dengan model pembelajaran peningkatan kemampuan berpikir (model 4) serta model lainnya. (2) Ada lima metode pembelajaran yang dipraktekkan pendidik pada jenjang pendidikan SMA yang representatif yaitu metode demonstrasi (metode 2) dibandingkan dengan metode simulasi (metode 5) serta metode lainnya. Metode belajar yang dapat ditterapkan dan diterima oeh peseta didik yaitu diskusi panel dan debat (metode 3) yang akan dibandingkan dengan metode bermain peran (metode 4) serta metode lainnya. (3) dari penelitian yang dilakukan mengenai model belajar kooperatif dan tradisional dapat dikatakan berhasil. Ini berarti guru dalam menerapkan model belajar modern dan konvensional selalu memperhatikan aspek efisiensi waktu pembelajaran, dengan menyesuaikan aspek efektivitas pemanfaatan media pembelajaran untuk memperoleh hasil belajar yang berkualitas, demikian pula dengan siswa menerima model belajar kooperatif serta tradisional sesuai dengan efisiensi waktu pembelajaran, efektif dalam menggunakan media pembelajaran dan menunjukkan hasil evaluasi pembelajaran yang berkualitas.

Sejalan dengan Kalsum Nasution (2017) Berdasarkan hasil penelitian tersebut maka dapat dibuktikan bahwa metode pembelajaran serta nilai pembelajaran peserta didik berada dikategori medium, serta terhadap hubungan yang kuat antara metode pembelajaran terhadap hasil belajar siswa, dengan demikian maka dapat dikatakan nilai belajar peserta didik dapat ditingkatkan dengan adanya penggunaan metode pembelajaran yang tepat dan baik oleh guru dalam proses pembelajaran di sekolah.

Sejalan dengan riset Yunita (2016) dapat disimpulkan bahwa sebelum menggunakan model belajar beregu diperoleh nilai mata pelajaran SKI peserta didik kategori nilai tinggi sejumlah 6 peserta didik $(21,43 \%)$, kategori sedang sejumlah 16 siswa $(57,14 \%)$ dan yang tergolong rendah enam peserta didik $(21,43 \%)$ dan nilai pelajaran SKI setelah menerapkan model belajar (Team Teaching) kategori baik sebanyak 
8 orang siswa $(28,57 \%)$, kategori sedang sebanyak 13 orang siswa $(46,43 \%)$ dan yang tergolong rendah 7 orang siswa $(25 \%)$. Hipotesis nihil yang diajukan ditolak karena besarnya " $t$ " yang peneliti peroleh dalam perhitungan (to $=8,768$ ) dan besarnya " $t$ " tabel. Nilai $\mathrm{t}$ (tt.ts.5\% = 2,05 dan tt.ts. $1 \%=2,77$ ) maka dapat kita ketahui bahwa to adalah lebih besar daripada tt; yaitu: 8,768 > 2,05 atau 8,768 > 2,77 sesuai dengan hasil penelitian dapat disimpulkan bahwa model belajar beregu dapat digunakan untuk mengajarkan bidang studi sejarah kebudayaan islam pada tingkat madrasah ibtidaiyah.

Berdasarkan hasil penelitian penerapan metode peer teaching mampu meningkatkan hasil belajar kalkulus. Adanya metode belajar yang sesuai dimaksudkan menghasilkan lingkungan pembelajaran yang kondusif sehingga tercipta suasana belajar aktif dan menyenangkan berdampak positif pada proses pembelajaran, nilai, serta hasil akhir yang maksimal. Metode pembelajaran digunakan dosen untuk menyajikan materi pelajaran kepada mahasiswai di dalam kelas baik secara individual atau secara kelompok agar materi pelajaran dapat diserap, dipahami dan dimanfaatkan oleh mahasiswa/i dengan baik (Ahmadi dan Prastya, 2005).

Metode pembelajaran mempermudah proses kegiatan belajar-mengajar. Keberhasilan suatu proses pembelajaran dapat diukur melalui seberapa banyak cara yang digunakan didalam mengajar (Sugiyono, 2006).

Dari hasil penelitian didapati metode pembelajaran berpengaruh terhadap peningkatan hasil belajar mahasiswa/i, dalam proses pembelajaran, dosen dapat menggunakan berbagai metode pembelajaran yang tepat dan sesuai dengan kebutuhan mahasiswa/i, dosen dapat menggunakan metode ceramah (Preaching Method), metode percobaan (Experimental method), metode latihan keterampilan (Drill method), metode diskusi (Discussion method), metode pemecahan masalah (Problem solving method), metode perancangan (projeck method), metode pembelajaran tersebut memiliki pengaruh yang kuat dan sedang terhadap peningkatan hasil belajar mahasiswa/i, setiap metode pembelajaran memiliki peranan dan keunggulan masing-masing, untuk itu diperlukan kemampuan dosen dalam menyesuaikan metode pembelajaran dalam proses pembelajaran.

\section{CONCLUSION}

\section{Simpulan}

Berdasarkan hasil penelitian, dapat ditarik simpulan bahwa hasil belajar kalkulus mahasiswa/i yang menggunakan metode peer teaching lebih tinggi daripada hasil belajar kalkulus mahasiswa/i yang menggunakan metode konvensional atau dapat dikatakan bahwa penerapan metode peer teaching mampu menaikkan nilai kalkulus mahasiswa/i. Metode peer teaching mampu membuat mahasiswa/i tidak malu untuk bertanya dan mampu meningkatkan aktivitas pembelajaran mahasiswa/i.

\section{Saran}

1. Bagi para dosen maupun guru hendaknya menjadikan pembelajaran dengan model pembelajaran tutor sebaya sebagai salah satu alternatif model pembelajaran yang digunakan di kelas.

2. Kemampuan afektif lainnya perlu dilakukan penelitian lanjutan agar mampu memahami dan dapat meningkatkan kompetensi afektif mahasiswa (ditinjau dari kemampuan afektif kelompok tinggi, menengah dan bawah) atas pemanfaatan model pembelajaran peer teaching. 


\section{REFERENCES}

Ahmadi. A., Prastya, J. T. (2005). Strategi Belajar Mengajar. Bandung: CV Pustaka Setia.

Airasian, Peter W., dkk. (2010). Kerangka Landasan untuk Pembelajaran, Pengajaran, dan Asesmen. Terjemahan A Taxonomy for Learning, Teaching, and Assesing: A Revision of Bloom's Taxonomy of Educational Objectives oleh Agung Prihantoro. Yogyakarta: Pustaka Pelajar.

Arikunto, Suharsimi. (2008). Penelitian Tindakan Kelas. Cetakan Ketujuh. Jakarta: Bumi Aksara.

Dhini Kurnia, Rizka. (2014). Pengembangan Model Pembelajaran Berbasis Cooperative Learning dalam Meningkatkan Motivasi Belajar Mahasiswa dan Peningkatan Mutu Lulusan Alumni Fasilkom Unsri Berbasis E-Learning (studi kasus: matakuliah pemrograman web). Jurnal Sistem Informasi (JSI), VOL. 6, NO. 1.

Dianawati Henny. (2015). Pengruh Penerapan Metode Peer Teaching Dalam Pembelajaran Matematika Terhadap Peningkatan Prestasi Belajar Siswa Kelas VI Sekolah Dasar Negeri Giring Ikecamatan Manding Kabupaten Sumenep.

Djamarah, S. B. (2008). Strategi belajar Mengajar. Bandung: Rineka Cipta.

Djamarah, S.B. \& Aswan Z. (2013). Strategi Belajar Mengajar. Jakarta: Rineka Cipta.

Hamdayana, J. (2016). Metodologi Pengajaran. Jakarta: PT Bumi Aksara.

Hayati, Isra. (2017). Pengaruh Model Pembelajaran Peer Teaching Terhadap Peningkatan Aspek Afektif Mahasiswa pada Mata Kuliah Akuntansi Keuangan Program Studi Perbankan Syariah Universitas Muhammadiyah Sumatera Utara. Jurnal Masharif al-Syariah: Jurnal Ekonomi dan Perbankan Syariah Vol. 2, No. 2, 2017 ISSN: 2527 - 6344 (Print) ISSN: 2580 - 5800 (Online).

Kalsum Nasution, Mardiah. (2017). Penggunaan Metode Pembelajaran Dalam Peningkatan Hasil Belajar Siswa. Jurnal Ilmiah Bidang Pendidikan Vol. 11, No. 1, 2017; ISSN 1978-8169.

Majid, A. (2013). Strategi Pembelajaran. Bandung: PT Remaja Rosdakarya.

Makarao, N. R. (2009). Metode Mengajar dalam Bidang Kesehatan. Bandung: Alfabeta.

Mulyatiningsih, E. (2011). Riset Terapan Bidang Pendidikan dan Teknik. Yogyakarta: UNY PRESS.

Nugria Bunga, Destri. (2016). Minat Mahasiswa Tentang Penerapan Metode Diskusi Dalam Proses Pembelajaran pada Program Studi Pendidikan Administrasi Perkantoran Fakultas Ilmu Sosial Universitas Negeri Makassar. Jurnal Office, Vol. 2 No 2, 2016.

Nuki Hastuti, Dena. (2018). Penerapan Metode Pembelajaran Tutor Sebaya untuk Meningkatkan Keaktifan dan Hasil Belajar Siswa pada Mata Pelajaran Desain Grafis Kelas X Multimedia 1 di SMK N 1 Godean. Skripsi. Yogyakarta: Universitas Negeri Yogyakarta.

Purwanto. (2016). Evaluasi Hasil Belajar. Yogyakarta: Pustaka pelajar.

Ratna Dewi, Erni. (2018). Metode Pembelajaran Modern Dan Konvensional Pada Sekolah Menengah Atas. Jurnal Ilmu Pendidikan, Keguruan, dan Pembelajaran Volume 2 Nomor 1 April 2018 hal 44-52 e-ISSN: 2549-9114 dan p-ISSN: 25499203.

S. E. Noersasongko and Y. T. C. Pramudi. (2009). "Jurnal Penyesuaian Dengan Modus Pembelajaran Untuk Siswa SMK kelas X," Jurnal Teknologi Informasi, vol. 5, pp. 741-756.

Schunk, D. H. (2012). Learning Theories: An Education Perspective (Teori-teori Pembelajaran:Perspektif Pendidikan Edisi Keenam). Diterjemahkan oleh: Eva Hamdiah, Rahmat Fajar. Yogyakarta: Pustaka Pelajar. 
Siregar, E. \& Hartini N. (2014). Teori Belajar dan Pembelajaran. Bogor: Ghalia Indonesia.

Sudjana, N. (2004). Dasar-dasar Proses Belajar Mengajar. Bandung: Sinar Baru Algensindo.

. (2005). Metode \& Teknik Pembelajaran Partisipatif. Bandung: Falah Production.

. (2014). Penilaian Hasil Proses Belajar Mengajar. Bandung: PT Remaja Rosdakarya.

Sugiyono. (2006). Metode Penelitian Pendidikan. Bandung: Alfabeta. . (2009). Metode Penelitian Pendidikan. Bandung: Alfabeta

Suprijono, A. (2015). Cooperative Learning Teori dan Aplikasi PAIKEM Edisi Revisi. Yogyakarta: Pustaka Pelajar.

Undang-Undang RI No. 20 Tahun 2003. Sistem Pendidikan Nasional. Jakarta: CV. Medya Duta.

Yunita, Inti. (2016). Penerapan Metode Mengajar Beregu (Team Teaching) dalam Meningkatkan Hasil Belajar Siswa Kelas IV pada Mata Pelajaran SKI di MI Muhammadiyah Ulak Lebar Kecamatan Ulu Ogan Kabupaten OKU. Jurnal Ilmiah PGMI Volume 2, Nomor 1, Januari 2016. 